\title{
JUŽNOSLOVANSKA GLASBA V ZGODOVINI EVROPSKE GLASBE*
}

\author{
Dragotin Cretko (Ljubljana)
}

Južnoslovanski narodi so šli $\mathrm{v}$ preteklosti skozi faze, ki so se med seboj zelo razlikovale. Doživljali so različne usode, ki so bistveno vplivale na njihovo kulturo in $\mathrm{s}$ tem ravno tako na glasbo. ${ }^{1} \mathrm{~S}$ tega vidika so bili z ene strani še zlasti važni njihovi stiki z Zahodom in Bizancem, ki so bili posebno aktualni in so postali za kulturno orientacijo posameznih narodov tako rekoč usodni s pokristjanjenjem, z druge pa njihovi odnosi s sosednimi državnimi strukturami, ki se vežejo na vprašanje samostojnosti posameznih južnoslovanskih nacionalnih skupnosti in njih prehajanje pod tuje nadoblasti.

Pokristjanjenje je povzročilo prve zveze posameznih južnoslovanskih narodov s krščansko kulturo, te pa so pomenile postopno sprejemanje in utrjevanje njenih vplivov, ki so prihajali iz dveh smeri: na srbski, bolgarski, makedonski in delno še dalmatinski prostor iz Bizanca, na slovenski in večji del hrvatskega prostora pa $\mathrm{z}$ Zahoda. $\mathrm{Tu}$ in tam so se uveljavili neodvisno od domačih kultur ali so se $\mathrm{z}$ njimi $v$ določenem smislu in obsegu tudi stapljali.

Viri, ki o tem pričajo, so skromni, skoraj jih ni. Kolikor so, pa dokazujejo, da so se tuji vplivi na različne načine odrazili v liturgični glasbeni praksi in $\mathrm{v}$ posvetni glasbi na dvorih fevdalne aristokracije, kjer in dokler je ta obstajala.

Na dvorih vladarjev in velikašev južnoslovanskega območja so delovali muziki, ki so oskrbovali glasbo na podoben način kot na zahodnoevropskih dvorih. Potujoči muzik je imel tu $v$ splošnem isto vlogo kot njegov zahodnoevropski vrstnik. Instrumenti, ki se jih je posluževal v svoji praksi, so bili različni. Freske $\mathrm{v}$ raznih samostanih in cerkvah, na

* Zaključno glavno predavanje na X. kongresu Mednarodnega muzikološkega društva v Ljubljani, septembra 1967.

1 Podrobno gl. Andreis J., Razvoj muzičke umjetnosti u Hrvatskoj v publ. Andreis, Cvetko, Đurić-Klajn, Historijski razvoj muzičke kulture u Jugoslaviji, Zagreb 1962; Đurić-Klajn S., Razvoj muzičke umetnosti u Srbiji, istotam; Gvetko D., Zgodovina glasbene umetnosti na Slovenskem I, II, III, Ljubljana 1958, 1959, 1960; Cretko D., Histoire de la musique slovène, Maribor 1967; Kovačević K., Hrvatski kompozitori $i$ njihova djela, Zagreb 1960; Krstev V., Očerki $v$ razvitii bolgarskoj muzyki, Sofija 1959; Bulgarische Musik, Musik in Geschichte und Gegenwart, II, 453-461 (S. Brašovanov); Jugoslawien, Kunstmusik, istotam VII, 306 do 336 (D. Cretko-J. Andreis-S. Đurić-Klajn-M. Pozajić-T. Skalovski). 
katerih so bili upodobljeni, in drugi viri kažejo, da so to bila raznih vrst godala, pihala, trobila in tolkala. Bili so ljudski instrumenti, kot jih je uporabljal preprosti človek, ali pa instrumenti, ki so bili tuji ljudski muzikalni praksi, so prišli od drugod in so bili namenjeni umetnemu posvetnemu muziciranju. Za njih upodabljanje $v$ likovni umetnosti je $\mathrm{z}$ ene strani možna razlaga, da so spadali v okvir ikonografskih pravil. Vendar je z druge strani treba njih rabo $v$ srednjeveškem slikarstvu na območjih, ki so jih obvladovali tako zahodni kakor bizantinski vplivi, pojmovati tudi tako, da se je zanje slikar zgledoval na primerih, ki jih je videl in poznal iz prakse. Tak način pojmovanja, ki je utemeljen, omogoča delno rekonstrukcijo muzikalnega instrumentarija, kakor se je uporabljal na fevdalnih dvorih južnoslovanskega območja in je $\mathrm{v}$ glavnem identičen $\mathrm{z}$ zahodno evropskm instrumentarijem.

Enako ali še bolj kot za posvetno so zunanji vplivi razumljivi za cerkveno glasbeno prakso, ki je bila na srbsko-makedonsko-bolgarskem prostoru $\mathrm{v}$ glavnem vsklajena $\mathrm{z}$ bizantinsko. $\mathrm{V}$ tem smislu se je nadaljevala in razvijala tudi po delitvi v vzhodno in zahodno cerkev. Vendar je zanjo značilno, da je sprejela tudi izdatne vplive posvetne ljudske pesmi. Vplivi torej niso bili samo $\mathrm{z}$ ene strani. Vršili so se tudi $\mathrm{v}$ obratni smeri. Cerkveno petje, kakor se je z določenimi specifičnimi potezami formuliralo na bolgarskem oziroma srbskem in makedonskem prostoru, je takšno tudi samo $\mathrm{v}$ nekem smislu vplivalo navzven.

Ob tem je omeniti prispevek, ki ga je v bizantinsko glasbo dal slovanski element z osebo Joana Kukuzela. Zanj so glede rojstnega leta in kraja in narodnostnega porekla navedbe različne. Gradivo, ki je na voljo, kaže, da je bil južnoslovanskega rodu in se je verjetno rodil nekje $v$ drugi polovici 14. stoletja. Velja za enega glavnih reformatorjev vzhodno pravoslavnega petja in notacije. $\mathrm{Z}$ njegovim imenom je zvezana uvedba neobizantinske neumatske notacije $\mathrm{v}$ vzhodno, ortodoksno cerkveno glasbo. ${ }^{2}$

$\mathrm{Na}$ slovenskem in večjem delu hrvatskega prostora je bila orientacija drugačna kot na srbsko-makedonsko-bolgarskem območju. Viri, ki jim je mogoče slediti v 10. oziroma 11. stoletje, kažejo tu in tam na neposredno zvezanost z rimsko cerkvijo. Gregorijanski koral je redno spremljal liturgične obrede. Ob njem pa se je $\mathrm{v}$ hrvatskem Primorju iz staroslovanskega obredja razvilo posebno, staroslovansko cerkveno petje. Znano je od 9.stoletja dalje, rabilo pa je ljudski in ne latinski jezik. Kakšno je bilo, natanko ni znano. Predajalo se je ustno, od generacije do generacije in se je zato spreminjalo. $\mathrm{V}$ izvirni obliki se ni ohranilo. $\mathrm{V}$ primerjavi z gregorijanskim koralom je bilo petje po vsej verjetnosti enostavnejše, brez melizmov, $\mathrm{v}$ glavnem silabično in le $\mathrm{v}$ posameznih primerih bogatejše okrašeno. Oficialna cerkev mu je dostikrat oporekala in ga tudi prepovedala, a se je $\mathrm{v}$ cerkveni glasbeni praksi navzlic temu držalo. $\mathrm{V}$ cerkvah senjske in krške škofije, kjer se je staroslovanska liturgija obdržala najdlje, se rabi glagolsko petje še danes, čeravno ne več enako, kot je bilo v prvotni, izvirni obliki.

2 GI. Palikarova-Verdeil R., La musique byzantine chez les Bulgares et les Russes du IXe au XIV siècle, Copenhague-Boston 1953, 193-209. 
Stiki z Bizancem in Zahodom oziroma z Bizancem ali Zahodom so potemtakem rezultirali tako, da so se južnoslovanske skupnosti v srednjeveškem razdobju v času svoje državne samostojnosti tudi z glasbene strani vključile v evropski okvir. Od njega niso samo sprejemale, ampak so mu v določeni meri tudi same dajale.

Ta situacija postane drugačna, ko posamezni južnoslovanski narodi izgubijo svojo državno samostojnost, vendar se spremembe povsod ne kažejo na enak način in tudi ne $\mathrm{z}$ istimi posledicami.

Izguba politične samostojnosti povzroči ekonomsko podrejenost, zmanjša možnosti za samostojno kulturno razvijanje in intenzivira vlogo tujih kultur. Za Slovence in Hrvate pomeni tuja, nemška in madžarska nadoblast vključitev $\mathrm{v}$ zahodno oziroma srednjeevropsko kulturno sfero z drugačnimi konsekvencami, kot so jim bili z več stoletij trajajočo turško prevlado podvrženi Srbi, Bolgari in Makedonci.

$\mathrm{V}$ času turškega gospodstva je na bolgarskem, makedonskem in srbskem nacionalnem prostoru kulturno življenje zlasti $\mathrm{v}$ smeri literarnega in likovnega snovanja in negovanja posvetne glasbe $\mathrm{v}$ glavnem zamrlo. $\mathrm{Z}$ instrumenti spremljano petje in ples, to in ono se je kajpak razvijalo med preprostim ljudstvom dalje. $V$ težkih razmerah podložništva in ravno zaradi tega so se ljudsko petje, glasba in ples celo močno razrasli. V določenem obsegu in načinu se je zdaj nadaljevala tudi cerkvena glasba.

O tem in onem pričajo za ta stoletja cerkveno slikarstvo, cerkveni spisi in zborniki cerkvenih spevov, pa še popotniki, ki so v času med 14. in 18. stoletjem spoznali balkanske dežele in so $\mathrm{v}$ svojih porcčilih opisovali, kar so glasbenega slišali in doživljali na svojih potovanjih. Med njimi so bili npr. Nicéphoras Grégoras (14. stol.), Bertrandon de la Broquière (15. stol.), Stephan Gerlach, Samuel Schweigger, H. Dernschwamm in K. Rym (16. stol.), Quiclet in E. Brown (17. stol.), Gerhard Cornelius Driesch (18. stol.) in drugi. Glasbeno so njihovi spisi ne samo zanimivi, ampak tudi značilni. Vsebujejo podatke o instrumentih, petju, plesu, oblikah glasbenega življenja, ki so jih spoznali ob raznih priložnostih med ljudstvom in na dvorih turških velikašev, skratka o vsem, kar je bilo v zvezi z glasbenim izživljanjem.

Cerkveno petje se je tu obdržalo navzlic turški zasedbi. V času od 15. do 18. stoletja pa so nastajali tudi novi spevi, ki so prešli v liturgični okvir in so se rabili v njem. Posebno značilne se zdijo tri himne domestika Stefana Srbina. Od njih sta se ohranili fotokopiji dveh himn, ki sta označeni kot Tvorenije domestika kir Stefana Srbina in sta obe melizmatični. Srbsko petje, za katerega srednjeveško razvojno fazo še ni jasno, ali so $\mathrm{v}$ njem tudi srbski elementi, je $\mathrm{v}$ fragmentih najti $\mathrm{v}$ glavnem $\mathrm{v}$ starocerkveni slovanščini ali njenem grškem ekvivalentu. Nekateri od muzikalnih rokopisov iz 18. stoletja, ki so v srbskem samostanu Hilandar na gori Athos in so $\mathrm{v}$ čast srbskih svetnikov, so $\mathrm{v}$ ruski cerkveni slovanščini in imajo poznobizantinsko notacijo. ${ }^{3}$ Podobne rezultate, kot jih je $\mathrm{v}$ tej smeri doslej dalo raziskovanje virov za srbski prostor, utegne dati tudi

3 Gl. Stefanovic D., The Serbian Chant from the 15th to the 18th Centuries, Musiqua antiqua Europae orientalis, Warszawa 1966, 140 ss. 
raziskovanje virov za druge južnoslovanske dežele, ki so bile pod turško nadoblastjo, za Makedonce in Bolgare.

Medtem ko se je cerkveno petje ohranilo in celo nadalje razvijalo in se je tudi ljudska glasba bogato množila, pa je bilo delo na področju umetne glasbe $\mathrm{v}$ razdobju turške nadoblasti minimalno ali ga sploh ni bilo. Z glasbo, ki je za isti čas znana za Zahodno Evropo, in z njenim razvojem ni imelo nič skupnega, od njega je bilo popolnoma izolirano. Razlike, ki so obstajale $\mathrm{v}$ kulturni orientaciji nasploh in tako tudi $\mathbf{v}$ glasbi že prej med slovenskim in hrvatskim prostorom na eni ter srbskim, bolgarskim in makedonskim prostorom na drugi strani, se s turško zasedbo južnoslovanskih pokrajin niso samo zvečale in poglobile, ampak so $\mathrm{v}$ razvojnih poteh umetne glasbe južnoslovanskih narodov privedle celo do diametralnih nasprotij: pri Srbih, Bolgarih in Makedoncih se je delo $\mathrm{v}$ smeri umetne glasbe za štiri oziroma pet stoletij in še več ustavilo in prenehalo, pri Slovencih in Hrvatih pa se ni in kaže povsem drugačno podobo.

Tuje gospodstvo, ki je Srbom, Bolgarom in Makedoncem preprečilo razvoj glasbene umetnosti, je bilo $\mathrm{v}$ nekem smislu negativno tudi za Slovence in Hrvate. Tudi njim ni dovolilo, da bi se $v$ glasbi v vsem oblikovali tako, kot so se neodvisni narodi Zahodne Evrope. Vendar je bilo zanje $\mathrm{v}$ danih razmerah tudi pozitivno. Predvsem zaradi tega, ker so slovenske in hrvatske pokrajine $v$ okviru državnih formacij, $v$ katerih so se znašle po izgubi politične samostojnosti, dobile stik z zahodno kulturo. Vanjo so se vključile in sprejele so njene dosežke. To jim je pozneje omogočilo, da so lahko neposredno sodelovale $\mathrm{v}$ zahodnoevropski glasbi. Viri o tem zgovorno pričajo.

Na slovenska in hrvatska tla so $\mathrm{v}$ srednjeveških stoletjih značilno segla umetnostna hotenja Zahodne Evrope. Odrazila so se $\mathrm{v}$ arhitekturi in cerkvenem slikarstvu. Spomeniki, ki to potrjujejo, so razmeroma obilni. Podobno kot z likovno umetnostjo je bilo tudi z glasbo, ki se je razvijala $v$ navedenem času na Slovenskem in Hrvatskem idejno enako ali sorodno kot v Zahodni Evropi. Njen razvoj se je vezal predvsem na samostane in cerkve, delno še na mesta. Ohranili so se številni neumatski kodeksi, od katerih je najstarejši na Slovenskem, Stiški rokopis datiran za 10, na Hrvatskem Evangeliarum absarense iz Osora pa za 11. stoletje. Ti kodeksi so bili prineseni od drugod ali so nastali $\mathrm{v}$ skriptorijih domačih samostanov. Časovno spadajo v razdobje od 10. do 15. stoletja in še pozneje ter potrjujejo zvezanost glasbenega dela hrvatskega in slovenskega ozemlja z razvojem tedanje evropske glasbe. Dejstvo njihovega obstajanja opravičuje trditev, da je za preučavanje neumatske notacije važen tudi ta prostor, ki ga potemtakem ni mogoče omejiti samo na črto RekaLjubljana-Gradec-Dunaj-Praga-Leipzig-Hamburg, ampak iz Slovenije razširiti še na severno Hrvatsko in na črto jugovzhodno od Reke, ob jadranski obali vse od Kotora. ${ }^{4}$

4 Prim. Suñol G., Introduction à la paléographie musicale grégorienne, Paris 1935; Vidaković A., I nuovi confini della scrittura neumatica musicale nell' Europa Sud-Est, Studien zur Musikwissenschaft, zv. 24, Wien 1961. 
Razen navedenih kodeksov obstajajo še drugi viri, ki pričajo o glasbenem delu na Slovenskem in Hrvatskem v času do konca 15. stoletja. $\mathrm{V}$ njih so podatki o pevskih šolah, organistih in drugih muzikih, ki so se aktivno udejstvovali na teh ozemljih. Omenjajo se tudi minnesängerji, meistersingerji, vaganti, za drugo polovico 15 . stoletja tudi že profesionalni muziki, ki so stopali v službo mest in plemstva. Ne samo iz cerkvenega slikarstva, ampak tudi iz pisanih virov so znani podatki o instrumentih in ustreznem instrumentalnem muziciranju. $O$ tem in gojitvi posvetne glasbe, a tudi o cerkveno glasbeni praksi je zapustil važen vir Paolo Santonino, ki je z vizitatorjem oglejskega patriarha Pietrom Carlom da Caorle in ostalim spremstvom $\mathrm{v}$ letih 1485-1487 obiskal slovensko ozemlje južno od reke Drave. ${ }^{5}$ Njegova pričevanja navajajo k sklepu, da se je v navedenem času na Slovenskem obilno gojila posvetna glasba in da je cerkvena glasba $v$ razdobju pozne gotike tu dosegla visok vzpon ter se je stilno vzporedila z idejno orientacijo sosednje Italije in zahodno evropskih dežel. Bila je, tako sodimo iz gradiva, sestavni del tedanje evropske glasbe.

Gradivo pravi, da so v poznih srednjeveških stoletjih glasbeniki slovenskega, hrvatskega in $\mathrm{v}$ posameznih primerih srbskega, a najbrž tudi bolgarskega in makedonskega rodu odhajali iz svojih ožjih domovin. Razmeroma izčrpni so $\mathrm{v}$ tej smeri podatki zlasti za slovenske in hrvatske glasbenike. Drugam jih je gnalo spoznanje, da utegnejo imeti na tujih, bogatejših dvorih za svoj umetniški razvoj boljše pogoje in širše možnosti. Te so se zvečale zlasti potem, ko so si posamezni posvetni in cerkveni knezi osnavljali svoje pevske kapele. Nekateri muziki so seveda ostali in delovali doma, vendar je bila njihova aktivnost pogosteje reproduktivna in redkeje ustvarjalna.

Podatki za muzike, ki so ostali doma, in one, ki so odšli v tujino, so za ta čas in še za pozneje nepopolni. Delno zato, ker so taki viri v domačih arhivih pomanjkljivi in tudi $\mathrm{v}$ evropskem merilu še niso $\mathrm{v}$ celoti raziskani. Še zlasti zato, ker so glasbeniki slovanskega, torej tudi slovenskega in hrvatskega rodu, svoja imena $\mathrm{v}$ tujini skoraj redno prilagodili tujemu pravopisu in izgovoru, oziroma so jih $\mathrm{v}$ skladu s tedanjimi navadami germanizirali, romanizirali ali latinizirali. To je pogosto zabrisalo sled. Prvotna oblika tega ali onega slovenskega in hrvatskega imena se odkrije včasih le po naključju, dostikrat pa je sploh ni mogoče rekonstruirati. Zato so iskanja in raziskovanja zapletena, še posebno za starejša obdobja. Marsikaterega skladatelja hrvatskega ali slovenskega rodu narodnostno zaradi teh razlogov verjetno ne bo mogoče dognati in bo za vselej ostal v nekem drugem narodnostnem okviru.

Izpod konca 15. stoletja so znane nekatere osebnosti slovenskega rodu, ki so sodelovale v razvijanju tedanje evropske glasbe. Tako Balthasar Praspergius Merspurgensis in Jurij Slatkonja (Chrysippus). Pridružuje se jima še Franciscus de Pavonibus, organist v Dubrovniku, čigar glasbeno delo podrobenje še ni znano in ga s te strani še ni mogoče pretehtati.

5 Gl. Cvetko D., Testimonianza di Paolo Santonino sulle condizioni della musica in Slovenia verso la fine del secolo XV, publ. Ettore Desderi, Bologna 1963. 
Kontinuiteta $\mathrm{z}$ zahodnoevropsko glasbo se je iz 15. nadaljevala $\mathrm{v}$ naslednja stoletja, vendar je bila še vedno podvržena raznim oviram.

$\mathrm{Ne}$ na Slovenskem in ne na Hrvatskem splošne razmere za glasbeno delo v 16. stoletju niso bile spodbudne. Družbena trenja so se ostrila, nasprotja med plemstvom in vladarjem so rasla. Tem in drugim činiteljem, ki so izvirali iz socialnih in političnih nagibov, so se pridružili še turški vpadi. Ti so bili pogosti na slovenskem in še zlasti na severnohrvatskem, a tudi na dalmatinskem ozemlju, kamor so $\mathrm{z}$ zahodne strani vpadali še Benečani, ki so si ga deloma tudi osvojili. Samo Dubrovnik si je kot samostojna republika znal ohraniti neodvisnost, zaradi česar je imel mnogo večje možnosti za intenzivno glasbeno življenje. Napetosti je v 16. stoletju zvečala še reformacija, ki je zajela slovensko in zahodni del severnohrvatskega ozemlja in delno Istro, dalje na vzhod in jug pa ni segla.

$\mathrm{V}$ mejah možnosti je glasbeno delo teklo naprej navzlic vsem tem in drugim oviram. Zanj so bili poleg cerkva še vedno važni samostani, čeravno je njihov splošni pomen že upadal. Pomembna torišča glasbenih prizadevanj so postajala tudi mesta, ki so bila $\mathrm{v}$ tem pogledu zelo aktivna. Za svoje potrebe so začela najemati stalne muzike, tako na primer Ljubljana in Dubrovnik. Ta je imel domače in tuje muzike $v$ svoji službi že v 15. stoletju in se je zatem glasbeno čedalje bolj razraščal.

Zaradi opisanih razlogov so bili pogoji za glasbeno delo precej različni. Relativno najugodnejši so bili v Dalmaciji in tu še posebno v Dubrovniku in na Slovenskem, manj ugodni, če že ne kar neugodni pa se kažejo za to in še za zadnji dve stoletji za severno Hrvatsko. Temu je treba za dobršen del tega časa pripisati vzroke $\mathrm{v}$ obrambnem značaju, ki ga je imel ta del hrvatskega ozemlja proti Turkom.

Dalmacija in Slovenija, obe sta se usmerili predvsem v italijansko glasbo. Dalmacija ne samo zaradi geografske bližine, ampak še zlasti zaradi trgovskih odnosov z Italijo in beneške oblasti nad velikim delom njenega ozemlja. Slovenija zato, ker je mejila na Italijo in je bila torej njen neposredni sosed. Vendar je ravno v 16. stoletju reformacija povzročila na Slovenskem močan dotok nemške protestantske glasbe. S tem so se tu za nekaj časa italijanski vplivi zmanjšali in omejili bolj na katoliški okvir. Gradivo pa pravi, da tudi iz protestantskega okvira niso bili popolnoma izločeni; zlasti potem, ko se je reformacija utrdila, so bili v njem relativno izdatni.

Domači glasbeniki so bili tudi zdaj aktivni tako na Slovenskem kot v Dalmaciji. Vendar je bila tudi njihova emigracija močna. Zanjo so vzroki v glavnem isti kot že prej, delno pa so jo večale še specifične, razmeroma neugodne razvojne razmere tega stoletja $\mathrm{v}$ domačih pokrajinah. Hkrati je značilno dejstvo, da sèm prihajajo v času, ko domači glasbeniki zapuščajo rodna tla, številni glasbeniki tujega rodu. V Dalmacijo iz Italije, ki je imela presežek glasbenikov. ${ }^{6} \mathrm{Na}$ Slovensko iz Nemčije, sèm gotovo zaradi reformacije, $\mathrm{ki}$ je tu za svoje širjenje in utrjevanje potrebovala sposobne muzike. V vrsti takih nemških protestantskih muzikov je bil tudi

${ }^{6}$ Prim. Plamenac D., Music of the 16th and 17th Centuries in Dalmatia, Papers read at the International Congress of Musicology (1939), New York 1944. 
skladatelj Wolfgang Striccius, v letih 1588-1591 kantor na stanovski latinski šoli v Ljubljani.

Tuji glasbeniki, naj so bili italijanski ali nemški, so s seboj prinašali ustrezne stilne orientacije, $\mathrm{ki}$ so se $\mathrm{z}$ njihovim delovanjem na slovenskem in hrvatskem prostoru še bolj utrjevale in širile.

Reformacija je po svoje tudi vplivala, da renesansa v 16. stoletju na Slovenskem ni imela enakega obsega kot $\mathrm{v}$ Dalmaciji, kjer so $\mathrm{v}$ višjih družbenih krogih precej negovali madrigal. $S$ te strani je treba torej za ta čas med Dalmacijo in Slovenijo ugotoviti določene razlike, ki pa se nanašajo bolj na kvantiteto kot na stilno orientacijo in kvaliteto glasbenih prizadevanj. Stilna usmeritev je bila ne glede na vprašanje obsežnosti reproduktivnih in ustvarjalnih storitev tu in tam $v$ načelu ista, hkrati pa taka kot $\mathrm{v}$ onih evropskih deželah, kjer je renesančna glasba doživljala svoj razcvet.

To potrjujejo z ene strani viri, kolikor so na voljo za glasbeno delo tega obdobja na slovenskih in hrvatskih tleh, z druge pa ustvarjalni dosežki skladateljev slovenskega in hrvatskega rodu. Med njimi so bili npr. skladatelj frottol Andrea de Antiquis; Franciscus Bossinensis, ki je objavil obdelave frottol raznih avtorjev in čigar transkripcije so prispevek tedanji solistični vokalno-instrumentalni glasbi, v nekem smislu predhodnici zgodnjebaročne monodije; komponist madrigalov Andrija Patricij (Petris); Julije Skjavetić (Schiavetti, Schiavetto), ki je pisal madrigale in motete, iz katerih so vidni vplivi Palestrinove dobe; Jurij Knez (Khness, Khnes, Khuess, Khüess, Khnies), komponist magnifikatov in drugih cerkvenih skladb; in Jacobus Gallus Carniolus, ki je na srednjeevropskem prostoru uveljavil tehniko beneške kompozicijske šole, jo še nadalje razvijal in se s svojimi mašami, moteti in posvetnimi zbori zaradi izvirnosti in kvalitete uvrstil med najpomembnejšse evropske skladatelje 16. stoletja. ${ }^{7}$

Vsi ti ustvarjalci so živeli in delali v 16. stoletju. Njihove skladbe so izšle samostojno v Benetkah, Pragi in drugod ali v pomembnih zbornikih tedanjega časa. Skoro vsi so delovali izven ožje domovine: de Antiquis na primer v Rimu in Benetkah, Bossinensis v Benetkah, Knez v Innsbrucku in v bavarski dvorni kapeli, Gallus v dunajski dvorni kapeli, v Olomoucu in Pragi. Samo Skjavetić je deloval doma, bil je v službi šibeniškega škofa. Rezultati v tujini delujočih ustvarjalcev so seveda veljali prostoru, na katerem so nastali in od koder so postali last širokega evropskega kulturnega prostora. Toliko so morda segli tudi v njihove ožje domovine, več in močneje pa najbrž ne.

Dosežki, ki jih je reproduktivno in ustvarjalno dal slovenski in hrvatski element v 16. stoletju, so se seveda prilagodili danim možnostim in mejam. Obsežni sicer niso bili, po svoji vrednosti in pomenu pa so za-

7 Prim. Škerjanc, L. M., Kompozicijska tehnika Jakoba Petelina-Gallusa, Ljubljana 1963; Cvetko D., Jacobus Gallus Carniolus, Ljubljana 1965; isti, Le probléme du rythme dans les oeuvres de Jacobus Gallus, Festschrift B. Stäblein, Kassel 1967; isti, Jacobus Gallus à Olomouc et à Prague, Sborník prací filosofické fakulty brněnske university XIV, F 9, Brno 1965; Jacobus Gallus, Harmoniae morales, Ljubljana 1966 (ured. D. Cretko). 
pustili vidno sled $v$ evropski glasbi tega časa. Ob njih je potrebno omeniti še razgibanost, ki jo je glasbi posredovala reformacija. ${ }^{8}$ Zaradi nje je mogla nastati tudi prva slovenska pesmarica »Eni psalmi (, natisnjena v letu 1567 z melodijami v menzuralni notaciji. S to pesmarico so se delno ohranile srednjeveške ljudske duhovne pesmi tega etničnega ozemlja. ${ }^{9}$

Česar renesansa v 16. stoletju zaradi navedenih vzrokov na Slovenskem ni mogla storiti, je $\mathrm{v}$ časovno kratkem, a presenetljivo bogatem razcvetu nadomestila ob koncu 16. in na začetku 17. stoletja. Tedaj so se z zaključkom reformacije na tem prostoru na široko odprla vrata v Italijo, odkoder so zdaj nemoteno in pospešeno pritekali dosežki novih glasbenih gibanj, poleg renesanse že tudi zgodnjega baroka. Dokaz za to je med drugim Inventarium librorum musicalium ecclesiae cathedralis labacensis iz leta 1620. Viri pripovedujejo o skoraj razkošnem glasbenem življenju na Slovenskem v prvih desetletjih 17. stoletja in o njegovi neposredni zvezanosti s sodobno zahodnoevropsko glasbo. Podobno, toda brez prejšnjih ovir, ki so bile značilne za Slovenijo, so cvetela glasbena prizadevanja v tem času tudi v Dalmaciji. Tu in tam se izdatno množijo glasbeniki, ki so bili domačega rodu in so delovali doma, kaže pa se tudi intenzivna glasbena storitev, ki je dala precejšnje rezultate tako na domačih tleh kot izven ožje domovine. Le na severnem Hrvatskem je bilo glasbeno delo še razmeroma skromno in se je omejevalo bolj na plemiške dvore.

Proces emigracije se nadaljuje $v$ obeh smereh tudi $v$ tem razvojnem obdobju: domači glasbeniki odhajajo drugam, tuji prihajajo na slovenska in hrvatska tla. Ti in oni imajo v bistvu to vlogo, ki so jo imeli že njihovi predhodniki. Muziki slovenskega in hrvatskega rodu prispevajo razvijanju glasbe $v$ širokem evropskem okviru, njihovi tuji vrstniki pa na slovenskem in hrvatskem prostoru. Med temi je bil zanimiv primer Tomaso (Toma) Cecchini, Italijan iz Verone, ki je na začetku 17. stoletja deloval najprej v Splitu in nato na Hvaru ter je pisal vokalne in instrumentalne kompozicije. Med temi so zlasti tehtne sonate, ki so po obliki $\mathrm{v}$ načinu zgodnjih trio- in solo sonat, kakršne so $\mathrm{v}$ tem času pisali italijanski skladatelji zgodnjega baroka. Ta Cecchinijeva dela so najstarejši ohranjeni primerki instrumentalne glasbe v Dalmaciji. Kot Cecchiniju v Dalmaciji gre na Slovenskem v določenem smislu sorodna vloga Isaacu Poschu (Poschius). Posch, čigar narodnostno poreklo še ni dokončno raziskano, je $\mathrm{s}$ svojimi variacijskimi suitami prispeval $\mathrm{k}$ razvoju tedanje evropske posvetne glasbe. Njegovo ustvarjanje se tesno veže na slovenska tla. To poleg drugega dokazujejo navedbe $\mathrm{v}$ njegovih zbirkah »Musicalische Ehrnfreudtc (1618) in »Musicalische Tafelfreudtc (1621).

Doma v Splitu je opravljal svoje delo Ivan Lukačić, skladatelj motetov, $\mathrm{v}$ katerih se kažejo dosežki italijanske zgodnjebaročne duhovne glasbe. ${ }^{10}$ Izšli so v zbirki 》Sacrae cantiones« (1620) in so bili deloma objavljeni v Donfridovem zborniku »Promptuarium musicum«.

8 Gl. Rijavec A., Glasbeno delo na Slovenskem $v$ obdobju protestantizma, Ljubljana 1967.

9 Gl. Cvetko D., Die Musik der slowenischen Protestanten, publ. Geschichte, Kultur und Geisteswelt der Slowenen, I, München 1968.

10 Plamenac D., Ivan Lukačić: Odabrani moteti (1620), Zagreb 1935. 
Drugi pomembnejši skladatelji začetnih desetletij 17. stoletja so delovali izven ožje domovine. Tako »symphonista ( barona Losensteina $v$ Loosdorfu na Nižjem Avstrijskem Daniel Lagkhner (Lackner), ki je bil rojen v Mariboru ob Dravi na Slovenskem in so v njegovih motetih vidni vplivi beneške šole, in kapelnik volilnega kneza v Mainzu Gabriel Plautzius (Plautz, Plautius, Plavec), ki je svojemu imenu dodal vzdevek Carniolus. ${ }^{11}$ Njegovo ustvarjanje je veljalo cerkveni glasbi in kaže $\mathrm{v}$ zbirki )Flosculus vernalis« (1621) elemente zgodnje monodije. Ne na Reki, kjer je bil rojen, ampak v Grazu in Zabernu (Alzacija) je deloval Vinko Jelić (Jelich), čigar duhovni koncerti za glasove s continuom in ricercari za kornet in trombon iz zbirke »Parnassia militiac( (1622) so usmerjeni v italijanski zgodnji barok. ${ }^{12}$ Bil je med prvimi skladatelji, ki so na nemško-avstrijskem prostoru $\mathrm{v}$ svojih cerkvenih skladbah razen orgel zahtevali še druge instrumente.

Od sredine 17. stoletja dalje za precej časa ni podatkov o vidnejših skladateljih v Dalmaciji. Razloge za to je najbrž treba iskati v pomanjkljivem gradivu in uničenih virih, pa tudi v postopnem manjšanju ekonomske moči tega ozemlja in zlasti Dubrovnika, ki so mu nove, drugod se odpirajoče pomorske poti postopoma odvzemale dosedanjo trgovsko vlogo in veljavo in s tem slabile tudi kulturno življenje. Kljub temu pa so bila na tem ozemlju glasbena prizadevanja še vedno precej živahna. Zlasti so jih bogatile italijanske operne družbe, ki so gostovale v Dubrovniku in izdatno vplivale na estetski okus občinstva in umetnostno orientacijo celotnega glasbenega dela. To se je $\mathrm{v}$ bistvu na enak način odrazilo na Slovenskem, kjer je za Ljubljano prva izvedba italijanske opere dokazana vsaj že za leto 1660 . Tudi tu so bili italijanski operisti poslej pogosti gostje. Razen njih je tu vplivalo na razvoj glasbenega življenja jezuitsko gledališče, še zlasti pa je vplivala v Ljubljani leta 1701 po zgledu italijanskih akademij osnovana Academia Philharmonicorum, ki je bila skoraj pol stoletja eden najvažnejših nosilcev glasbenega baroka na slovenskih tleh. ${ }^{13}$

Kot prej se je tudi zdaj, v obdobju visokega in poznega baroka glasbeno delo na Slovenskem in $\mathrm{v}$ Dalmaciji stilno usmerilo $\mathrm{v}$ glavnem tako kot v Italiji. Vplivi so bili na teh ozemljih v bistvu isti kot drugod v zahodnem evropskem prostoru, kjer je tudi imela italijanska glasba še vedno izdatno vlogo.

Za ta čas od sredine 17. do sredine 18. stoletja kaže ustvarjanje precejšnje rezultate. Obsežnejše reproduktivne možnosti so omogočile občutno pomnožitev domačih skladateljev, ki so ostali na domačih, slovenskih tleh

11 Prim. Skladatelji Gallus / Plautzius / Dolar in nijhovo delo - Les compositeurs Gallus / Plautzius / Dolar et leur oeuvre, Ljubljana 1963 (ur. D. Cvetko)'.

${ }^{12}$ Gl. Vidaković A., Vinko Jelić $i$ njegova zbirka duhovnih koncerata $i$ ricercara "Parnassia militia«.(1622), Zagreb 1957.

13 Gl. Cvetko D., Academia Philharmonicorum Labacensis, Ljubljana 1962; isti, Contribution à la question sur l'année de la fondation de l'Academia Philharmonicorum Labacensis, Festschrift W. Wiora, Kassel 1967; isti, Leges Academiae Phil-Harmonicorum Labaci metropoli Carnioliae adunatorum, Acta musicologica XXXIX, 1967. 
in tu delovali. Zanje navajajo viri, da so pisali glasbo za uprizoritve jezuitskega gledališča, oratorije, serenade, trio sonate in kompozicije raznih drugih oblik s področja posvetne in cerkvene glasbe. Med njimi so izpod konca 17. in iz prvih desetletij 18. stoletja J. G. Hozhevar (Gottscheer, Gotscheer, Gottseer, Hočevar), Marijan Tshadesh (Čadež), Mihael Omerza, J. Berthold pl. Höffer, J. J. Labasser pl. Laubenburg, Wolfgangus Conradus Andreas Siberau, J. B. Polec (Poliz, Polz) in J. Blatnik (Wlatnig, Blatnig). V Ljubljani je sredi 17. stoletja začel in nato $\mathrm{v}$ Passau nadaljeval svoje skladateljsko delo jezuit J.B. Dolar, ki se je s svojimi sonatami in baleti uvrstil med značilne predstavnike visokega baroka evropske glasbe. Zanimiva osebnost poznega baroka italijanske smeri je bil Giuseppe Clemente Bonomi, »maestro di capellac kranjskega vicedoma. $V$ libretu njegove, leta 1732 v ljubljanski vicedomski palači uprizorjene opere »Il Tamerlano je posvetilo knezu Francescu Antoniu Sigifridu della Torre e Valsassina. V njem pravi Bonomi, da ima s pričujočim delom namen počastiti potomce svojega genija $\mathrm{v}$ tej slavni vojvodini, namreč vojvodini Kranjski, kjer njegovim prednikom ni bila usojena samo zibelka, temveč so $\mathrm{v}$ njej mnogo stoletij tudi srečno živeli ( )Con il presente però Drama non altro intendo, che cominciare ad onorare i deboli parti del mio ingegno in questo Inclito Ducato ove i miei Antavi non solo ebbero in sorte di averne la Cuna, mà per più, e più Secoli goderono un felice soggiorno( ). Njegov rod je gotovo bil italijanski. Iz omenjene stilizacije pa sodimo, da je ta rod tu, na slovenskih tleh živel že nekaj generacij sèm. Tako kaže, da Bonomija ni mogoče imeti za tujca na Slovenskem. Ta skladatelj je za zgodovino slovenske glasbe važen predvsem zato, ker je bila njegova opera »Il Tamerlano« po dosedanjih podatkih prva te vrste, ki je bila ustvarjena na slovenskih tleh. ${ }^{14}$

$\mathrm{V}$ sredini in na začetku druge polovice 18. stoletja se je barok enako kot drugod zaključil tudi na Slovenskem in v Dalmaciji. Nekaj časa zatem se je še skušal nadaljevati, a ne več v čisti obliki, marveč že obarvan z elementi predklasike. To potrjujejo skladbe nekaterih avtorjev začetnih desetletij druge polovice 18. stoletja, tako npr. Dubrovčana Luke Sorkočevića, slovenskega skladatelja Jakoba Zupana (Suppan), ki je bil avtor prve doslej znane izvirne slovenske opere »Belin ( $(1780$ ali 1782$)$, in Amandusa Ivančiča (Ivanschitz, Ivanczitz, Ivantzitz), za katerega pa pomanjkljivo biografsko gradivo zdaj še ne dovoljuje, da bi ga narodnostno uvrstili v slovensko ali hrvatsko glasbo, a je gotovo, da spada $\mathrm{v}$ eno od teh dveh.

Težnje za nadaljevanjem baroka niso uspele. Nova stilna naziranja so postajala tudi na Slovenskem in Hrvatskem vedno razločnejša. Kažejo se $\mathrm{v}$ delih nekaterih skladateljev druge polovice 18. in začetka 19. stoletja, tako Antuna Sorkočevića, v Splitu delujočega Julija Bajamontija, čigar simfonije so po strukturi blizu tipu klasične simfonije, in Ljubljančana J. B. Novaka, ki je leta 1790 napisal glasbo h komediji »Veseli dan ali Matiček se ženi(c A. T. Linharta z naslovom »Figaro« in jo zasnoval v na-

14 Prim. Cvetko D., Il Tamerlano de Giuseppe Clemente Bonomi, publ. Essays presented to Egon Wellesz, Oxford 1966. 
činu zgodnjega Mozarta. V tej zvezi je še omeniti v Dubrovniku rojenega Ivana Mane Jarnovića (Jarnovich, Giornovichi), ki pa ni deloval doma, temveč v Parizu in je bil violinist evropskega slovesa. ${ }^{15}$ Med njegovimi številnimi skladbami so najzanimivejši violinski koncerti, ki veljajo za predhodnike francoskega koncerta druge polovice 18. stoletja. Vanje je skladatelj v srednjem stavku prvič uvedel romanco. Stilno jih je pisal pod Mozartovim vplivom in bogato koloriral $v$ smislu rabe francoskega rokokoja.

Spremembe, ki jih kaže glasba na Hrvatskem in Slovenskem v drugi polovici 18. stoletja, so bile velike. Ne samo v stilni preorientaciji, ki pomeni ob zaključevanju 18. stoletja dokončen prehod $\mathrm{v}$ klasiko in tako postopen odmik od nekaj stoletij trajajoče dominacije italijanske glasbe. V zvezi s presnavljanjem tedanje evropske družbe in specifičnimi pogoji tega dela južnoslovanskega etničnega prostora se glasbena situacija ne spreminja samo umetnostno. Ne toliko na Slovenskem, kjer se kontinuiteta nadaljuje brez večjih vnanjih previranj, pač pa na Hrvatskem. Dalmacija je že nekaj časa sèm izgubljala svojo nekdanjo vlogo in z njo Dubrovnik, ki je s francosko zasedbo prenehal obstajati kot samostojna republika - Antun Sorkočević je bil njen zadnji poslanik v Parizu. Na mesto Dalmacije stopa severna Hrvatska $\mathrm{z}$ Zagrebom kot osrednjim mestom. Ta je doslej z glasbene strani dala le manjše rezultate, med ka* terimi izstopa delo Jurija Križanića, avtorja zanimivega glasbenoteoretskega spisa »Asserta musicalia ( $(1656),{ }^{16}$ in historično pomemben zbornik cerkvenih pesmi z napevi )Cithara octochordac( $(1701,1723,1757) . \mathrm{Ob}$ prehajanju $v 19$. stoletje pa se začne na tem delu hrvatskega prostora intenzivno glasbeno delo, ki kmalu pridobi na šrini, kvaliteti in pomenu.

V obdobju klasicizma se je tako na Slovenskem kot na Hrvatskem vzpela zlasti reprodukcija. Ta je bila na ravni, ki nasploh ni zaostajala za ravnijo reprodukcije $\mathrm{v}$ pomembnejših evropskih središčih takratnega časa. Rezultati ustvarjanja pa so bili precej skromni. Razlogi za to niso bili samo $\mathrm{v}$ tedanji družbeni situaciji, $\mathrm{v}$ kateri se plemstvo umika in končno umakne meščanstvu, kar je $\mathrm{v}$ posledicah začasno zmanjšalo obseg umetnostnih naporov. Iskati jih je treba tudi $\mathrm{v}$ odsotnosti nekaterih domačih osebnosti, ki so živele in ustvarjale $\mathrm{v}$ tujini, npr. Ljubljančana F. Pollini v Milanu in J. Mihevec (Micheuz, Michéuz, Miheuz, Micheaux) na Dunaju ter v Parizu. Tuji, kreativno šibkejši, večidel češki glasbeniki, ki so zato, da bi našli zaposlitev, že prej, a zdaj še $\mathbf{v}$ večjem številu prihajali na Slovensko in Hrvatsko, niso odtehtali manjkanja ustvarjalno izrazitejših domačih skladateljev.

Komaj se je po kratkem obdobju klasicizma na Slovenskem in Hrvatskem uveljavil romantizem, so se že pojavili činitelji, ki niso imeli nobene neposredne zveze $\mathrm{z}$ umetnostjo, a so vendar bistveno segli $\mathrm{v}$ nadaljnji razvoj na obeh omenjenih etničnih ozemljih, obenem pa so bili velikega po-

15 Prim. Djurić-Klajn S., Ivan Mane Jarnović, contemporain de Mozart, Bericht über den internationalen musikwissenschaftlichen Kongress Wien, Mozartjahr 1956, Graz-Köln 1958.

16 Prim. Vidaković A., »Asserta musicalia« (1656) Jurja Križanića $i$ njegovi ostali radovi s područja glazbe, Zagreb 1965. 
mena tudi za ostali južnoslovanski prostor. Vsebinsko so se strnili v narodnostnih osvobodilnih gibanjih, ki so zajela vse južnoslovanske narode $\mathrm{s}$ težnjo za ponovno pridobitev nacionalne, politične in ekonomske in $\mathrm{s}$ tem tudi kulturne samostojnosti. Ta gibanja so pri teh narodih nastopila $\mathrm{v}$ prvi polovici 19. stoletja. Odvijala so se $\mathrm{v}$ različnih oblikah in pod različnimi pogoji ter možnostmi. Rezultirala so $\mathrm{v}$ ponovni pridobitvi neodvisnosti južnoslovanskih narodov proti koncu 19. in na začetku 20. stoletja.

Boj za osvoboditev je v 19. stoletju neposredno prispeval k nastajanju oziroma orientaciji glasbenega dela pri posameznih južnoslovanskih narodih. V uresničevanju ciljev narodnostnih gibanj je bila potrebna tudi glasba. Zaradi tega tam, kjer se je glasba kontinuirano razvijala in negovala že skozi stoletja, to je na Slovenskem in Hrvatskem, nekje od tridesetih let navedenega stoletja dalje, za nekaj časa stil in umetniška kvaliteta kompozicij nista bila osrednji problem, ampak sta se podredila interesom narodnostnih gibanj. Vse težnje so se usmerile v en sam cilj, ki se ni oziral na vezanost slovenske in hrvatske glasbe $\mathrm{z}$ novimi idejami zahodnoevropske glasbe, ampak na oblikovanje narodno zavednega Slovenca oziroma Hrvata. Skladateljem, ki so se izrekli za narodnostno gibanje in njegove ideje, so bili nacionalni cilji prvi in nad umetnostnimi. Njihovemu ustvarjanju je bil izhodišče nacionalizem, ki je vsebinsko in časovno različno pogojen $\mathrm{v}$ tem času nastajal tudi pri drugih evropskih narodih.

Glasbeni nacionalizem se je v evropskem okviru pojavil vsaj v dveh oblikah, politično in duhovno. Politično tako, da je s sklicevanjem na liberalna in humanitarna načela zahteval svobodo nekega naroda. Duhovno se je odrazil v stremljenju po spoznanju bistva nekega naroda. Ne zato, da bi ta služil samemu sebi, ampak zato, da bi se vključil v svetovni okvir in bi s tem $\mathrm{v}$ razvoju sodeloval ne glede na meje, ki so sicer med narodi. Ta orientacija je bila značilna predvsem za neodvisne narode, ki jim boj za osvoboditev ni bil potreben, ker so bili svobodni. V posameznih primerih jo je mogoče zaslediti tudi pri samostojnih narodih in pri teh razločno takrat, ko se je njihov boj za neodvisnost bližal koncu.

Razlika med obema orientacijama je jasna. Prva, politična je bila vsaj na začetku omejena na etnične meje. Druga, duhovna je bila širša in manj občutljiva ali celo neobčutljiva za te meje. Ta in ona sta neposredno vplivali na idejno usmeritev glasbe, ki ravno tako kaže dve varianti. Prva, ki jo je povzročil politično pogojen nacionalizem, je šla svojo razvojno pot in se je morala ozirati na specifične pogoje. Drugi možnosti, katere temelji so sloneli na duhovno pogojenem nacionalizmu, pa se na neke posebne pogoje ni bilo treba vezati.

Prva možnost se je izrazila pri odvisnih narodih, med katerimi so bili v 19. stoletju tudi Slovenci in Hrvati. Usmerjala pa je tudi Bolgare in Srbe, ki jih je potreba spodbudila $\mathrm{k}$ temu, da so glasbo vključili med sredstva za doseganje ciljev svojih osvobodilnih gibanj. To je povzročilo, da se je po njihovi večstoletni izločitvi iz evropskega 'kulturnega postora začela pri njih umetna glasba znova razvijati, za kar so bili pogoji v novo nastajajočih ali novih nacionalnih situacijah $\mathrm{v}$ temelju ugodni. 
$\mathrm{V}$ trenutku, ko so si začeli južnoslovanski narodi prizadevati za pridobitev ponovne samostojnosti, se je začela glasba pri njih odvijati na način, ki je ustrezal ciljem nacionalnih gibanj. V slovenski in hrvatski glasbi je to pomenilo korak nazaj in je vodilo $\mathrm{k}$ začasni prekinitvi $\mathrm{z}$ dotedanjo evropsko glasbeno tradicijo, hkrati pa $v$ orientacijo, ki je bila značilna za začetek razvijanja umetne glasbe pri Srbih in Bolgarih nekaj pred koncem prve oziroma sredi druge polovice 19. stoletja ter pri Makedoncih ob koncu tega stoletja. Z vidika stilne usmeritve in oblik glasbenega dela so se na ta način vsi južnoslovanski narodi v teku večjega dela 19. stoletja ne glede na zelo različne preteklosti znašli $\mathrm{v}$ istem ali podobnem položaju. ${ }^{17}$

Ustvarjalna prizadevanja so se izrazila različno. Tako, da so se glasbene oblike sprva omejile na področja, ki so zahtevala idejno značilne tekste, na zbor in samospev. Tako, da so ustvarjalci poenostavili kompozicijsko tehniko in prilagodili stil potrebam, da bi bila njihova dela dostopnejša širokim množicam, ki so bile glavni dejavnik $\mathrm{v}$ uresničevanju nacionalnih gibanj. In tako, da so vnesli $\mathrm{v}$ svoje skladbe elemente, $\mathrm{ki}$ so bili blizu občutjem preprostih ljudi. Značilnosti ljudske pesmi in glasbe so rabili v obliki citatov, stilizirano ali pregneteno sǩozi lastna, individualna občutja. To je streglo tudi težnjam za konkretizacijo glasbenega nacionalizma in razvijanju samobitnih, od tujih vplivov kar najbolj neodvisnih nacionalnih kultur.

Te naloge so bile sprva zahtevne. Pri Srbih in Bolgarih so bile zaradi pomanjkanja tradicije in redkih ustvarjalcev težje izvedljive kot pri Slovencih in Hrvatih. Narodnostnim gibanjem predani skladatelji niso bili kdove kako številni in vedno tudi ne dovolj spretni v kompozicijski tehniki. Zato so bili dobrodošli tudi taki, katerih kompozicije so bile tehnično zelo preproste in celo pomanjkljive. Nekateri poskusi tega časa spominjajo na glasbena prizadevanja izza začetkov reformacije v 16. stoletju - misel na tako analogijo se zdi upravičena, kajpada s pripombo, da so bila idejna izhodišča zdaj popolnoma drugačna in možnosti ter perspektive ravno tako.

Dosežki prve faze tega razvojnega obdobja so bili v prvi vrsti torej odvisni od nalog in ciljev, ki so jim služili. V mnogih primerih jim gre bolj nacionalna in politična kot umetniška vrednost. $V$ nadaljevanju razvoja pa se je glasbeno delo kmalu razširilo, odvisno od uspehov posameznih skladateljev. Število ustvarjalcev se polagoma množi. Tudi oblike, v katerih so nastajala njihova dela, ves čas niso bile iste. Poleg vokalnih so se začele pojavljati še skladbe s področja klavirske, komorne, orkestralne in gledališke glasbe.

Stilno je to razvojno fazo težko natanko definirati. V načinu oblikovanja, rabe kompozicijskih sredstev in pojmovanju formiranja melodičnih linij so bili klasicistični prijemi na začetku še izraziti ali celo vodilni. Postopoma so se jim pridružili elementi romantičnega stila, ki so postali zlasti proti koncu te faze razločni.

17 Prim. Cvetko D., Die Situation und die Probleme der slowenischen, kroatischen und serbischen Musik des 19. Jahrhunderts, Bericht über den internationalen musikwisseschaftlichen Kongress Kassel 1962, Kassel 1963; isti, The Problem of National Style in South Slavonic Music, Slavonic Review XXXIV, 1955. 
Prvi ustvarjalni napori so uspeli navzlic oviram. V glasbenih prizadevanjih južnoslovanskih narodov so se $v$ tem času začeli risati obrisi samobitnih nacionalnih glasbenih kultur, ki so $\mathrm{z}$ ene strani upravičili po dolgem presledku obnovljeno razvijanje in na nove temelje postavljeno formiranje srbske ter bolgarske, pozneje tudi makedonske glasbe, z druge pa utemeljili začasen prelom slovenske in hrvatske glasbe $\mathrm{s}$ tradicijo in evropsko sodobnostjo.

$\mathbb{V}$ zadnjih desetletjih 19. stoletja se je glasbena romantika uveljavila pri vseh južnoslovanskih narodih. Italijanski vplivi, ki so se umikali že izpod konca 18. stoletja dalje, so se zdaj še bolj omejili, zrasli pa so nemški. Ti so podobno kot drugod v Evropi segli tudi v romantiko južnoslovanskih glasbenih kultur, $\mathrm{v}$ katerih so bili vidni tudi vplivi poljske in češke glasbe, $\mathrm{v}$ srbskem romantizmu pa pozneje še vplivi ruskega romantičnega realizma. Glasbeni nacionalizem, ki je na južnoslovanskem prostoru pognal korenine na samem začetku nacionalnih gibanj in se je idejno manifestiral že pred sredino in na začetku druge polovice 19. stoletja npr. z V. Lisinskim in K. Stankovićem, se proti koncu tega stoletja ni le nadaljeval, ampak se je idejno še utrdil in umetniško poglobil, tako $\mathrm{s}$ St. St. Mokranjcem, ${ }^{18}$ in J. Marinkovićem, ${ }^{19}$ F. Kuhačem in E. Manolovim ter $\mathrm{v}$ določenem smisu tudi z B. Ipavcem, torej pri Srbih, Hrvatih, Bolgarih in Slovencih.

$\mathrm{Z}$ vidika specifičnih razvojnih pogojev so bili rezultati glasbene romantike pri južnih Slovanih kar obilni, $v$ primerjavi z uspehi tedanje zahodnoevropske glasbe pa so bili skromni. Zaradi opisanih razmer se je romantika na tem etničnem prostoru zamudila. Tudi to je vplivalo, da se tu ni mogla odraziti $v$ vseh finesah, ki so sicer bile značilne za ta stil $v$ evropskem merilu.

Fin de siècle pomeni zaključevanje romantike in nastop novih stilnih spodbud, ki se pri južnoslovanskih narodih sicer povsod ne pojavijo istočasno, vendar časovno tudi ne kažejo bistvenih razlik. Razmeroma naglo, kakor naj bi se nadomestilo, kar se je zamudilo v preteklosti, se uveljavijo pozna in nova romantika in impresionizem, vselej $\mathrm{z}$ izdatno prisotnostjo elementov nacionalnih stilov. Ti so $\mathrm{v}$ okviru novih glasbenih gibanj živi tudi zdaj, na začetku 20. stoletja in še pozneje. Manj v slovenski glasbi, čemur je menda treba iskati razlago $v$ njeni večji zvezanosti $z$ zahodno kulturo, ki je bila dovolj tesna tudi $\mathrm{v}$ prehodnem obdobju začasne prekinitve, in bolj $\mathrm{v}$ hrvatski, srbski, bolgarski in makedonski glasbi.

Že v drugem desetletju 20. stoletja prodre na južnoslovanski prostor tudi ekspresionizem, najprej $\mathrm{v}$ slovensko in nato postopoma $\mathrm{v}$ glasbo drugih južnoslovanskih narodov. Z njim se tudi tu začne obdobje moderne, ${ }^{20}$ ki pomeni za slovensko in hrvatsko glasbo ponovno vrnitev $\mathrm{v}$ evropsko glasbo, od katere ti dve nista samo sprejemali, ampak sta z delom ustvar-

18 Gl. Konjović P., Stevan St. Mokranjac, Beograd 1956.

19 Gl. Peričić V., Josif Marinković, Život i dela, Beograd 1967.

20 Prim. Zvuk št. 77-78, 1967, 33-43 (Z. Kučukalić), 51-60 (K. Kovačević), 61-65 (D. Ortakov), 78-87 (R. Pejović), 94-99 (A. Rijavec); Kovačević K., The History of Croatian Music of the Twentieth Century, Zagreb 1967; Cvetko D., Les nouvelles orientations dans la musique slovène, Le livre slovène III, 1966. 
jalcev slovenskega in hrvatskega rodu vanjo stoletja tudi konstruktivno prispevali, za srbsko, bolgarsko in pozneje še makedonsko glasbo pa dokoněno vzključitev $\mathrm{v}$ evropski okvir.

Poslej so se do danes v glasbah južnoslovanskih narodov konkretizirali vsi sodobni evropski stilni tokovi in njihovi odtenki, ki so tipični za sedanje stanje glasbe $\mathrm{v}$ svetu. Nastali so relativno obilni in kvalitetni rezultati, ki seveda povsod niso enaki in tudi časovno niso usklajeni, saj se individualno in nacionalno pogojene razvojne možnosti med seboj razlikujejo. Obseg in stopnja ustvarjalnih uspehov sta odvisni od osebnosti in kreativne moči ustvarjalca. Ta bo o podobi in razvojni vlogi slovenske, hrvatske, srbske, bolgarske in makedonske glasbe $\mathrm{v}$ nacionalnem in svetovnem merilu odločal tudi zdaj na analogen način, kakor je $v$ načelu in praksi odločal že $\mathrm{v}$ preteklosti vse od trenutka, ko so se ti etnični prostori začeli vezati $\mathrm{z}$ evropsko glasbo.

\section{SUMMARY}

In their past the Southern Slavonic peoples have gone through certain phases of development, all of which have a very different character. For their music the contacts with Western Europe and with Byzantium were of particular importance and with christianization they became even so to say fatal for their cultural orientation. Sources giving evidence of this are at first rare, yet they prove that the foreign influences were reflected in sacred music as well as in the secular music at the courts of the aristocracy. In Serbia, Macedonia and Bulgaria the ecclesiastical musical practice mainly followed the Byzantine pattern. It is characteristic that it received also considerable influence from secular folk-songs. In Slovenia and the greater part of Croatia sacred music reveals direct contacts with the Roman Church. Liturgical rites were regularly accompanied by Gregorian Chant and on the Adriatic coast of Croatia also the Old Slavonic Chant was practised.

The loss of political independence meant for Slovenes and Croats incorporation into the Western and Middle European cultural spheres. This entailed consequences quite different from those in Serbia, Macedonia and Bulgaria where, owing to their subjection to Turkish domination for several centuries, there was only the possibility for a continuation of their church music and not of their artistic, secular music. The Slovenes and Croats, however, received the achievements of Western music and so they began to take a direct part in the Western European musical development. Evidence of this is given by numerous neumatic codices and other sources.

The contact with Western European development remained in Slovenia and in Croatia, particularly in Dalmatia, in the fifteenth as well as in the following centuries. In both areas we observe primarily an orientation to Italian music. It is due to the Reformation that in Slovenia the Renaissance in the $16^{\text {th }}$ century had not the same intensity as it had in Dalmatia. However, this movement greatly increased the musical activity and gave rise to the first printed Slovene song book, »Eni Psalmi« (1567) with melodies in mensural notation.

In the Renaissance period a number of composers of Slovene and Croatian extraction are known. Some of them worked at home but the greater part of 
them were active abroad, so making an important contribution to the development of European music. The same is valid for the Baroque period when conditions further improved and the musical life became intensified.

In Slovenia and Dalmatia the Baroque period came to an end largely in the middle of the $18^{\text {th }}$ century and by the end of this century the transition to Classicism was completed. It is also important to mention that, at that time, the centre of gravity for music was transferred from Dalmatia to Northern Croatia. There, as well as in Slovenia, musical Classicism began to flourish at the end of the $18^{\text {th }}$ century, equally in musical performance and in composition. After a short period of this style in Slovenia and Croatia, Romanticism came to the fore, yet it was temporarily interrupted by the national movement. This movement meant in the development of musical style a step backward for all Southern Slavonic peoples in the nineteenth century. Only after national movement had attained and consolidated its first successes, was it possible for art to flourish fully. And the considerable achievements of Romanticism in the second half of the 19th century among all Southern Slavs illustrate this. At the beginning of the $20^{\text {th }}$ century neo-romanticism, impressionism and expressionism - with elements of national style - each in their turn came to the fore in the Southern Slavonic area. This meant for Slovene and Croat music a return once again to contemporary developments in European music: as had been common in previous centuries, they not only received new elements from this tradition but also, in the case of certain composers of Slovene and Croat extraction, made their own contributions to it. For Serbian, Bulgarian and Macedonian music the advent of Modern period meant that they became a definite element in European musical trends. Since then among all Southern Slavonic peoples all contemporary musical trends have been realised. However, contemporary musical works have achieved fruitful successes on a national and European scale. 